\title{
INTERNATIONAL WEIGHTS AND MEASURES
}

T HE Proceedings of the forty-ninth session of the International Committee of Weights and Measures held during October 4-20, 1960, have now been published*. It contains the reports of the secretary of the Committee covering the period September 1 , 1958-August 31, 1960; the director, Mr. Volet, of the International Bureau of Weights and Measures, on the activities of the Bureau during the same period; the commission for the revision of the treaty of the metre; the consultative committee for ionizing radiation standards; the commissions on system of units; and the commissions on the work and administration of the Bureau.

The International Committee recommended, and this was later adopted by the eleventh General Conference on Weights and Measures, that the metre be the length equal to $1,650,763 \cdot 73$ wave-lengths in vacuo of the radiation corresponding to the transition between the levels $p_{10}$ and $5 d_{5}$ of krypton-86; the definition of the metre in vogue since 1889 , based on the international prototype of platinum iridium, be abrogated; and the international prototype sanctioned by the First Conference of Weights and Measures in 1889 be preserved at the International Bureau of Weights and Measures under the same conditions as those fixed in 1889. The Conference also confirmed the recommendation that the Inter-

* Bureau International des Poids et Mesures, Sevres. Comptes Rendus des Séances de la Onzième Conférence Générale des Poids et Mesures, Paris, 11-20 Octobre 1960. Pp. 144. (Paris: Gauthiervillars et Cie., 1961.) national Bureau undertake the work of international unification of the standards of measurement of ionizing radiation, and the extension of the laboratories of the Bureau and the increase of its equipment for this purpose. In this connexion, the Bureau would take charge of the international standard of radium No. 5430 which the Radium Institute of the University of Paris was willing to have transferred. The Committee was asked to undertake without delay the necessary investigations to fix precisely the units and ideas used in regard to ionizing radiation and to submit its findings to the twelfth General Conference to be held in 1966.

It was agreed that the cubic decimetre and the litre were not equal, but differed by about 28 millionths, and that a report on this matter should be presented to the twelfth General Conference.

The full texts of the sixteen resolutions adopted by the eleventh General Conference are printed in the Comptes Rendus des Séances de la Onziéme Confèrence Générale des Poids et Mesures $\dagger$. Appendix 5 to this volume is the official French version of the International Practical Scale of Temperature of 1948 (amended edition of 1960), and Appendix 6 gives a detailed description of the progress of the International System of Units based on the metre, kilogramme, second, ampere, degree $K$ and candela.

\section{S. WeInTroub}

† Comité International des Poids et Mesures. Procès-Verbaux des Seances, 2 $2^{\mathrm{e}}$ Série, Tome 28 (49* Session, 1960). Pp. 161. (Paris:
Gauthier-Villars et Cle., 1962.)

\section{A RADIOISOTOPE TECHNIQUE FOR TRACING AIR MOVEMENTS IN CLEAR AIR AND IN CLOUDS}

\author{
By R. A. FOOKES and J. S. WATT \\ Isotopes Division, Australian Atomic Energy Commission \\ AND \\ J. A. WARBURTON \\ Radiophysics Division, C.S.I.R.O., Sydney
}

\begin{abstract}
A detected by a large crystal scintillometer. From the measurements of $\gamma$-ray intensity, the movement of the tracer may be followed and information obtained on its spatial distribution.

The method has been tested in ten separate flight experiments. In the first two xenon-133 was used; but this was abandoned in favour of the more readily available copper-64 (half-life $12 \cdot 8 \mathrm{~h}$ ) in the form of finely powdered copper oxide. Up to 2 . curie quantities of ${ }^{61} \mathrm{CuO}$ have been
\end{abstract}

NEW technique using radioisotopes for tracing air movements in clear air and in clouds is being developed principally for use in experiments related to cloud seeding. The tracer is released from an aircraft and, during a series of passes, the $\gamma$-rays emitted by the material about the aircraft are

released and traced with an omnidirectional scintillation detector for periods up to $50 \mathrm{~min}$. A typical flight record of one pass through a cloud is given in Fig. 1. It shows the variation of detected radiation intensity as the aircraft passed the radioisotope about $1.6 \mathrm{~min}$ after its release. The

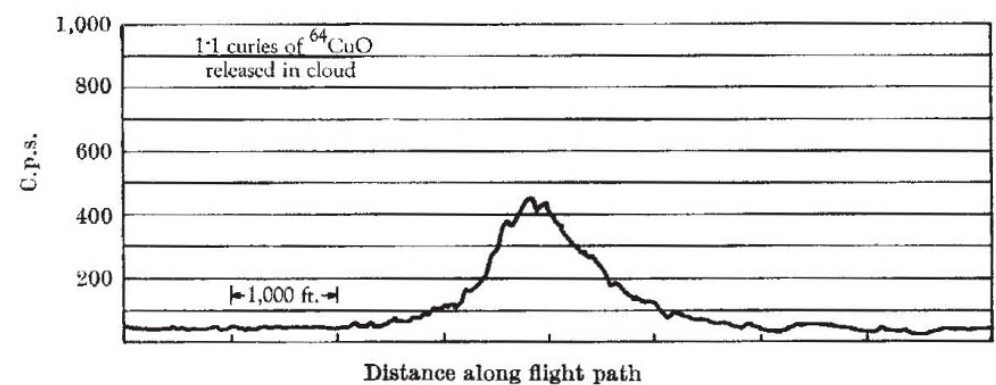

Fig. 1. Record of variation of $\gamma$-ray intensity along flight path 